\title{
Zoonotic and anthropozoonotic potential of COVID-19 and its implications for public health
}

\author{
Amr El-Sayed ${ }^{1} \cdot$ Mohamed M. Abdel-Daim $^{2,3} \cdot$ Mohamed Kamel $^{1}$ (B) \\ Received: 16 November 2020 / Accepted: 5 September 2021 / Published online: 14 September 2021 \\ (C) The Author(s), under exclusive licence to Springer-Verlag GmbH Germany, part of Springer Nature 2021
}

\section{Introduction}

Coronaviruses belonging to the Coronaviridae family are enveloped, single-stranded, positive-sense RNA viruses. Several members of coronaviruses can infect man and animals to induce respiratory and enteric diseases. To date, seven coronaviruses $(-\mathrm{CoV})$ are known to be human pathogens, namely HCoV-NL63, HCoV-229E, HCoV-OC43, HKU1, SARS-CoV, MERS-CoV, and SARS-CoV-2 (Contini et al. 2020). While SARS-CoV, MERS-CoV, and SARS-CoV-2 (betacoronaviruses) are responsible for serious and even fatal respiratory diseases, the remaining four viruses (HCoV-NL63 and HCoV-229E (alpha CoVs), and both HCoV-OC43 and HKU1 (beta CoVs)) are linked to 10 $30 \%$ of the common cold and mild respiratory infections which can be accidentally fatal. Five out of these seven viruses (with the exception of $\mathrm{HCoV}-\mathrm{OC} 43$ and HCoV-HKU1) seem more likely to have speciated from ancestor bat-associated viruses (El-Sayed and Kamel 2021). Both HCoV-OC43 and HCoV-HKU1 are likely to have direct ancestral links with rodents representing as their primordial hosts. Their human transmissions may occur via domestic animals such as pigs or cattle (Corman et al. 2018, Lau et al. 2015). Whether the viral

Amr El-Sayed and Mohamed Kamel contributed equally to this work.

Responsible Editor: Philippe Garrigues

Mohamed Kamel

m_salah@cu.edu.eg

1 Department of Medicine and Infectious Diseases, Faculty of Veterinary Medicine, Cairo University, Giza 12211, Egypt

2 Department of Pharmaceutical Sciences, Pharmacy Program, Batterjee Medical College, P.O. Box 6231, Jeddah 21442, Saudi Arabia

3 Pharmacology Department, Faculty of Veterinary Medicine, Suez Canal University, Ismailia 41522, Egypt spillover required an intermediate host or was transmitted directly from bats to humans is not always known (Table 1) (Wu et al. 2020, Singla et al. 2020, El-Sayed and Kamel 2021). Over the past 20 years, in 2002, 2012, and 2019, serious new coronaviruses emerged for the first time, namely, SARS-CoV, MERS-CoV, and SARS-CoV-2. All of the three viruses had a zoonotic potential and represented a great public health threat (Tables 2, 3, and 4 and Figure 1) (Sharun et al. 2021, El-Sayed and Kamel 2021).

Since the emergence of SARS-CoV-2 in Wuhan, the virus carried out continuous mutation and progressive evolution. Among the main initiators for continuous mutations is the ability of SARS-CoV-2 to easily cross the interspecies barrier. Such mutations aim to adapt the viral genome to its new host species. For instance, in 2002, SARS-CoV required only two mutations (K479N and S487T) to spill over from palm civet to humans. Understanding the adaptation process can help in the control of possible epizootics (Garry 2021).

Moreover, in a recent work, mapping of 2034 different SARS-CoV-2 mutations could detect five antibody neutralization escape mutations of the virus (Starr et al. 2021). Out of these, three mutations raised extra worry: the UK (VOC 202012/01 (B.1.1.7 lineage)), the South African (VOC 202012/02 (B.1351 lineage)), and the Brazilian Amazon (VOC 202101/02 (P.1)) variants (Burki 2021). This concern is based on the alarming data about higher fatalities among patients infected with the B.1.1.7 lineage when compared with other patients. In addition, this mutation is characterized by its higher spread rate and ability to escape from vaccinal protection (Iacobucci 2021, Muik et al. 2021, Supasa et al. 2021). SARS-CoV-2 continuous mutation represents a serious challenge for the international public health and the intensive efforts to control the pandemic through mass vaccination. The present work focuses on the zoonotic and reverse zoonotic aspects of SARS$\mathrm{CoV}-2$ and the most serious mutations of the virus. 
Table 1 The table lists the seven human pathogenic coronaviruses and provides an overview of their reservoir and intermediate hosts, year of discovery, and the needed receptors for a successful invasion

\begin{tabular}{|c|c|c|c|c|c|c|}
\hline $\begin{array}{l}\text { Zoonotic } \\
\text { coronaviruses }\end{array}$ & $\begin{array}{l}\text { Genus and } \\
\text { subgenus }\end{array}$ & $\begin{array}{l}\text { Natural } \\
\text { reservoir }\end{array}$ & $\begin{array}{l}\text { Intermediate } \\
\text { host }\end{array}$ & $\begin{array}{l}\text { Year of } \\
\text { discovery }\end{array}$ & Receptors & Reference \\
\hline SARS-CoV & $\begin{array}{l}\beta-C o V / \\
\text { Sarbecovirus }\end{array}$ & \multirow[t]{5}{*}{ Bats } & $\begin{array}{l}\text { Civets } \\
\text { Raccoon }\end{array}$ & 2002 & ACE2 & $\begin{array}{l}\text { (Wu et al. 2005) } \\
\text { (Freuling et al. 2020) }\end{array}$ \\
\hline MERS-CoV & $\begin{array}{l}\beta-\mathrm{CoV} / \\
\text { Merbecovirus }\end{array}$ & & $\begin{array}{l}\text { Dromedary } \\
\text { camels }\end{array}$ & 2012 & DPP4 & (Azhar et al. 2019) \\
\hline SARS-CoV-2 & $\begin{array}{l}\beta-\mathrm{CoV} / \\
\text { Sarbecovirus }\end{array}$ & & $?$ (Table 2) & 2019 & ACE2 & (Zhu et al. 2020) \\
\hline HCoV-NL63 & $\begin{array}{l}\alpha-C o V / \\
\text { Setracovirus }\end{array}$ & & $?$ & 2004 & ACE2 & (Hofmann et al. 2005) \\
\hline $\mathrm{HCoV}-229 \mathrm{E}$ & $\begin{array}{l}\alpha-C o V / \\
\text { Duvinacovirus }\end{array}$ & & $\begin{array}{l}\text { Dromedary } \\
\text { camels }\end{array}$ & 1966 & Aminopeptidase N (CD13) & $\begin{array}{l}\text { (Gagneur et al. 2002, } \\
\text { Corman et al. 2018, Lim } \\
\text { et al. 2016) }\end{array}$ \\
\hline $\mathrm{HCoV}-\mathrm{OC} 43$ & $\begin{array}{l}\beta-\mathrm{CoV} / \\
\text { Embecovirus }\end{array}$ & Rats & $\begin{array}{l}\text { Cattle and } \\
\text { swine }\end{array}$ & 1967 & $\begin{array}{l}\text { Glycan-based receptors carrying 9-O-acetylated } \\
\text { sialic acid and major histocompatibility } \\
\text { complex class I (HLA class I) }\end{array}$ & $\begin{array}{l}\text { (Gagneur et al. 2002, } \\
\text { Corman et al. 2018, Lim } \\
\text { et al. 2016, Collins 1994) }\end{array}$ \\
\hline HCoV-HKU1 & $\begin{array}{l}\beta-\mathrm{CoV} / \\
\text { Embecovirus }\end{array}$ & & $?$ & 2005 & $\begin{array}{l}\text { Glycan-based receptors carrying 9-O-acetylated } \\
\text { sialic acid and the major histocompatibility } \\
\text { complex class I C molecule (HLA-C) }\end{array}$ & $\begin{array}{l}\text { (Abdel-Moneim and } \\
\text { Abdelwhab 2020, Lim } \\
\text { et al. 2016, Chan et al. } \\
\text { 2008) }\end{array}$ \\
\hline \multicolumn{7}{|c|}{ Possibly zoonotic coronaviruses (in experimental studies) } \\
\hline SADS-CoV & $\begin{array}{l}\alpha-\mathrm{CoV} / \\
\text { Rhinacovirus }\end{array}$ & & Swine & 2017 & Not identified & $\begin{array}{l}\text { (Edwards et al. 2020, Yang } \\
\text { et al. 2020b) }\end{array}$ \\
\hline
\end{tabular}

\section{Ongoing potential for SARS-CoV-2 transmission}

The ongoing potential for zoonotic and anthroponotic SARSCoV-2 transmission was highlighted following reports of viral spillover from animal to man transmission (mink to human) (Salajegheh Tazerji et al. 2020, Jo et al. 2020, Singla et al. 2020, Oude Munnink et al. 2020), and reverse spillover from human to animal transmission (man to dog and man to cat) (Salajegheh Tazerji et al. 2020, Mallapaty 2020, CDC 2020a, OIE 2020c). Since then, several studies were carried out to investigate the ability of SARS-CoV-2 to infect different animal species (Tables 2 and 4).
SARS-CoV-2 is believed to originate from horseshoe bats. However, the intermediate host of SARS-CoV-2 remains unknown (Swelum et al. 2020, El-Sayed and Kamel 2021). For the detection of the intermediate host of SARS-CoV-2, the serological approach was used by Zhang and his team (2020) who investigated sera from 35 different animal species (Zhang et al. 2020c). In parallel, the molecular approach for the determination of possible intermediate hosts was carried out by Dames and his team. To achieve this goal, the team determined first the susceptible (potential target) animal species which own the required receptors for SARS-CoV-2 binding. The team studied the angiotensin-converting enzyme 2 (ACE2) sequences of 410 vertebrate species, including 252
Table 2 Although the intermediate host of SARS-CoV2 between bats and man is not definitely known, the table lists the animal species suggested to play an epidemiological role as SARS-CoV-2 intermediate hosts

\begin{tabular}{ll}
\hline Possible SARS-CoV-2 intermediate host & Reference \\
\hline Pangolin & $\begin{array}{c}\text { (Tang et al. 2020, Wong et al. 2020, Lam et al. 2020, } \\
\text { Zhang et al. 2020e, Singla et al. 2020) }\end{array}$ \\
Bamboo rats & (Kumar O.R. et al. 2020) \\
Civets & (Kumar O.R. et al. 2020) \\
Turtle & (Liu et al. 2020, Hobbs and Reid 2020) \\
Frogs & (Zhang et al. 2020a) \\
Bovidae & (Luan et al. 2020) \\
Mink & (Oude Munnink et al. 2021). \\
Snakes (were excluded later from the list & (Ji et al. 2020, Gautam et al. 2020) \\
of possible intermediate hosts) &
\end{tabular}


Table 3 The zoonotic potential of SARS-CoV, MERS-CoV, and SARS-CoV-2 viruses is presented. The three viruses are batborne viruses and spread later to infect humans and other animal species

\begin{tabular}{llc}
\hline Coronavirus & Susceptible species & References \\
\hline SARS-CoV & $\begin{array}{c}\text { Bats, human, primates, raccoon dog, red fox, ferret, } \\
\text { chicken, mink, civet cat, field rat, pigs }\end{array}$ & $\begin{array}{c}\text { (Gautam et al. 2020, Chen et al. } \\
\text { 2005, Wang et al. 2005) }\end{array}$ \\
MERS-CoV & $\begin{array}{c}\text { Bats, human, primates, dromedary camels, alpaca, } \\
\text { cattle, sheep, goat, buffaloes, donkey, horse, llama }\end{array}$ & $\begin{array}{c}\text { (Gautam et al. 2020, Vergara-Alert } \\
\text { et al. 2017, Wit et al. 2013) }\end{array}$ \\
SARS-CoV-2 & $\begin{array}{c}\text { Bats, human, dog, snake, pangolin, cats, ferrets, and } \\
\text { other species (Table 4) }\end{array}$ & Table 4 \\
& & \\
\hline
\end{tabular}

mammals for their binding affinity to SARS-CoV-2 (Damas et al. 2020). This step was followed by focussing on animal species that might play a role as intermediate hosts for SARSCoV-2 according to the ACE2 analysis profiles (Damas et al. 2020) (Table 2).

The study of Dames and his team (2020) and similar designed studies provided valuable data not only about possible intermediate hosts but also about animal species that might maintain the virus in circulation by acting as reservoir hosts. Out of the 103 investigated species, receptor analysis referred to the possible role of 21 species of primates, including Angola colobus and rhesus macaques, in addition to various species of cervid deer and cetacean species as SARS-CoV-2 potential reservoir. Two-thirds of the involved artiodactyl mammals (e.g., domesticated large and small ruminants, wild ruminants, as well as giraffe, gazelle, okapi, hippopotamus, and scimitar-horned oryx) showed a medium score for ACE2-
SARS-CoV-2 binding. Rodents varied in their susceptibility according to their species. Meanwhile, camels are unlikely to play a role in disease spread, although they are susceptible to other coronaviruses (Damas et al. 2020).

Among the susceptible farm animal species, the small and large ruminants could be infected with SARS-CoV-2 (Praharaj et al. 2020, Deng et al. 2020), water buffaloes (Praharaj et al. 2020), rabbits (Santini and Edwards 2020, Praharaj et al. 2020), horses (Santini and Edwards 2020, Praharaj et al. 2020), and pigeons (Frutos et al. 2020). Meanwhile, the poultry and farmed birds (except pigeons) are resistant to infection (Suarez et al. 2020). On the other hand, the role of pigs in the spread of SARS-CoV-2 is debated. While some reports confirm their epidemiological role (Wu et al. 2020), other reports list pigs among the animals of no epidemiological importance for COVID-19 transmission (Schlottau et al. 2020). The severity of clinical signs in

Table 4 The table enumerates the known animal species to be either susceptible or resistant to infection by SARS-CoV-2

\begin{tabular}{llll}
\hline SARS-CoV-2 susceptible species (besides human and bats) & Serology & Virus isolation & Reference \\
\hline Dog & Yes & No & (Sit et al. 2020, OIE 2020c) \\
Cat & Yes & Yes & (OIE 2020b, 2020a, CDC 2020a) \\
Tigers & Yes & Yes & (APHIS 2020) \\
Lions & Yes & Yes & (APHIS 2020, USDA 2020, OIE 2020b, Jo et al. 2020) \\
Fox & Yes & Yes & (Praharaj et al. 2020) \\
Mink & Yes & Yes & (Oreshkova et al. 2020) \\
Ferrets & Yes & Yes & (Shi et al. 2020, Kim et al. 2020) \\
Monkey & Yes & Yes & (Munster et al. 2020, Lu et al. 2020) \\
Rhesus macaques, tree shrews, cynomolgus macaques, & Yes & Yes & (Oude Munnink et al. 2021) \\
$\quad$ and African green monkeys & Yes & Yes & (Bao et al. 2020) \\
Mice & Yes & Yes & (Sia et al. 2020, Chan et al. 2020, Bao et al. 2020) \\
Hamsters & Yes & ? & (Zhao et al. 2020) \\
Tree shrew & Yes & Yes & (Jo et al. 2020) \\
Raccoon & Yes & Yes & (Santini and Edwards 2020, Praharaj et al. 2020) \\
Rabbits & Yes & Yes & (Santini and Edwards 2020, Praharaj et al. 2020) \\
Horses & Yes & Yes & (Praharaj et al. 2020, Deng et al. 2020) \\
Large and small ruminants & Yes & Yes & (Praharaj et al. 2020) \\
Water buffaloes & &
\end{tabular}

Non-susceptible animal species including guinea pig, mouse, pigs, European hedgehog, lesser hedgehog tenrec, chicken, and ducks were found referent to vulnerability (Ruiz-Arrondo et al. 2020)(Shi et al. 2020; Schlottau et al. 2020)(Wu et al. 2020, Suarez et al. 2020) 


\section{Zoonotic potential of SARS-CoV, MERS and SARS-CoV2 viruses}

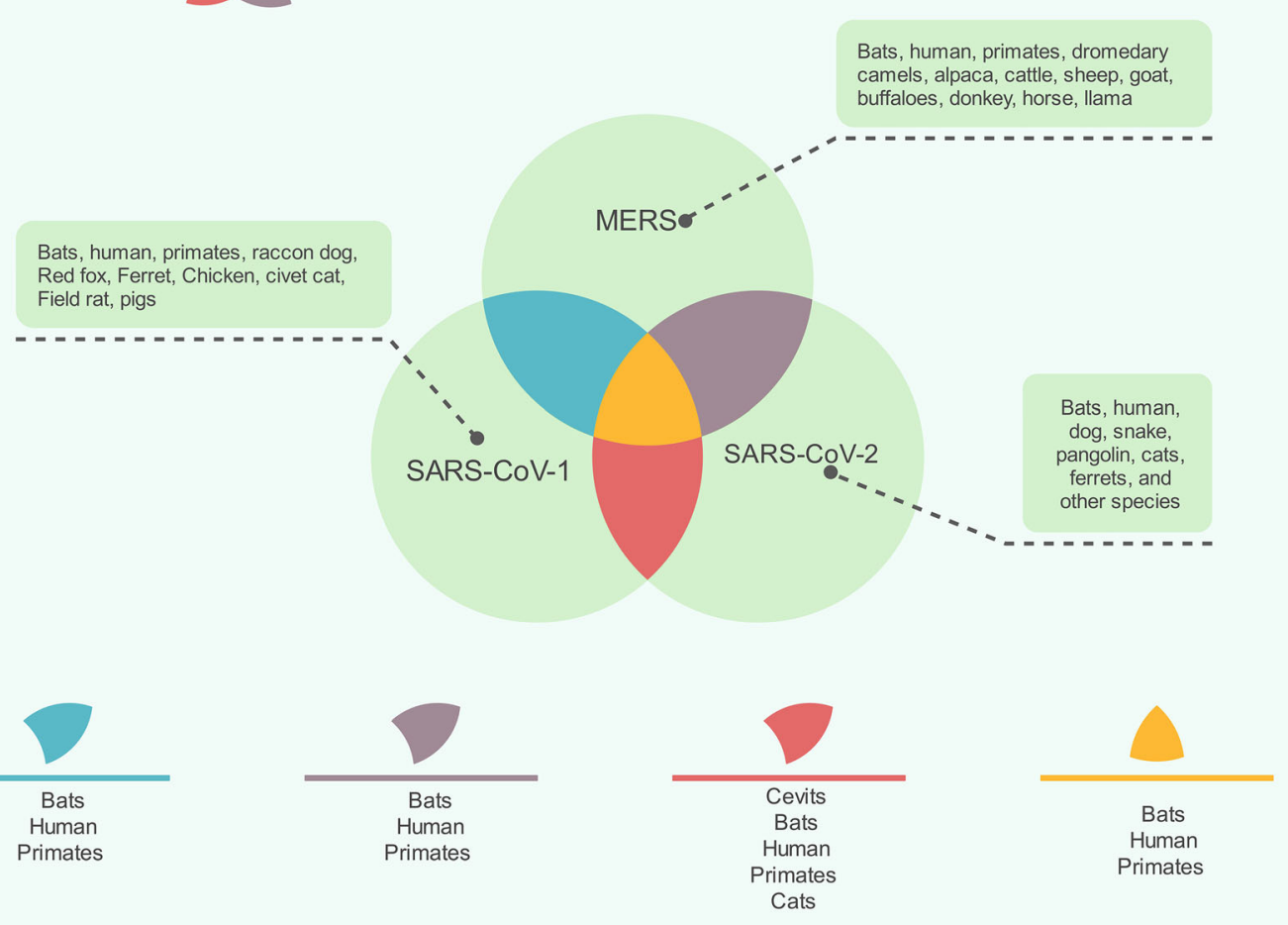

Figure 1 Zoonotic potential of SARS-CoV, MERS-CoV, and SARS-CoV-2 viruses

animals varies in relation to the species susceptibility to the virus being almost asymptomatic in dogs, associated with moderate respiratory and/or gastrointestinal disorders in cats, and severe and almost fatal in minks (Hobbs and Reid 2020).

Although the high susceptibility of mink to SARS-CoV-2 infection is known since summer 2020, the decision of culling all farmed minks in Denmark was taken in the 5 th of November after it was clear that the virus can spill back from mink to humans, and that the virus can mutate in the infected minks. The new mutations arose widespread public health concern as they occurred in the viral spike (S) glycoprotein, responsible for receptor binding. Such mutations may develop different invasion strategies to human cells and may not respond to already developed vaccines and therapies which may have catastrophic consequences on the international public health (Koopmans 2021, Frutos and Devaux 2020, Hammer et al. 2021). A third reason explaining the panic and public health concern in relation to mink infections is the high evolutionary rate of the virus in mink population when compared to its evolutionary rate in human or other animal species. The high density of animals in the cages allows not only the rapid uncontrolled spread of the virus in the population but also the subjection of human workers to higher viral load due to the high mink density in farms, which can potentially shorten the generation interval for SARS-CoV-2 in humans (normally ranges around 4 to 5 days) (Oude Munnink et al. 2021).

The international concern was calmed down through the culling of the entire farmed mink population (15 million farmed minks) in Denmark, Spain, and the Netherlands. Later on, SARS-CoV-2 could be isolated from wild freeranging American mink (Neovison vison) in Utah, USA (OIE 2021). In addition to wild free-ranging minks, the virus could also hit several mink farms in Utah, leading to severe economic losses. Mink to human viral transmission was reported where there were several staffers on Utah farms who attracted the infection after coming in contact with infected animals (Stout et al. 2021, Shriner et al. 2021, Cahan 2020). In addition to the USA, mink to human viral transmission could be confirmed in the Netherlands, Spain, Italy, Sweden, and Greece (Koopmans 2021).

The high susceptibility of minks to SARS-CoV-2 associated with virus exposure in high density populations in the farms favor sustained and rapid virus transmission. In the USA, not only mink with respiratory signs tested positively to SARS-CoV-2 but also other apparently healthy animals in the farm. The virus could spread from infected mink to infect healthy mink, and even dogs and cats in the farm (CDC 2020b). Phylogenetic analysis of SARS-CoV-2 isolates 
detected in mink farms in the Netherlands revealed the presence of at least five different SARS-CoV-2 clusters (A, B, C, $\mathrm{D}$, and $\mathrm{E}$ ) which clustered with human isolates. Epidemiological data analysis indicated the zoonotic transmission of the virus from the farmed mink to the farm workers; however, the source of new human infections among the workers was not only limited to infected minks (Oude Munnink et al. 2020, Oude Munnink et al. 2021). In spite of their clustering in different clusters, and although several mutations were detected upon blasting the sequence of Wuhan strain with the Danish mink isolates, no amino acid substitutions occurred in all investigated mink samples. However, the high sequence diversity of mink isolates indicates the infection's persistence for several generations and its circulation in the mink population for a long time before being discovered (Oude Munnink et al. 2021).

The evolved minks' SARS-CoV-2 mutations in Denmark and the Netherlands circulated faster in mink and human population than the original wild strains. A mink-associated $\mathrm{S}$ protein mutation (Y453F mutation) was detected in all mink isolates from Denmark and several farms in the Netherlands. In this mutation, tyrosine substitution with phenylalanine at amino acid 453 occurs in the RBD region (receptor binding domain). The substitution in position 453 in viral $\mathrm{S}$ protein contacts the ACE2 receptors at position 34, which differs between human (Histidine) and mink (Tyrosine), which indicates the adaptation of the virus to mink cellular receptors (Larsen et al. 2021, Lassaunière et al. 2020).

However, the lack of the $\mathrm{Y} 453 \mathrm{~F}$ in mink isolates indicates its minor role in the disease pathogenesis in minks. The Y453F mutation was also isolated from human patients in Russia, the USA, and South Africa without known history of mink contact. Meanwhile, the $\mathrm{S}$ protein (S1 subunit) of about half of the mink isolates from Denmark poses an additional deletion of histidine and valine amino acids (positions 69 and 70). The same mutation was also reported in human patients in the UK, France, Germany, Norway, Sweden, Malaysia, New Zealand, Australia, Canada, and Côte d'Ivoire (Oude Munnink et al. 2021, Welkers et al. 2021).

Although the cluster-five SARS-CoV-2 mutation Y453F did not provide an additional advantage to the virus such as reduction of antibody neutralization capacity or escape from vaccinal protection, it enhanced the viral transmission process the providing fourfold higher ACE2 receptor binding affinity in comparison to the wild-type RBD-spike binding potential (Rafael Bayarri-Olmos et al. 2021).

In mink isolates, additional mutations were also reported in $\mathrm{S}$ protein sequence, including the I692V and M1229I mutations (Oude Munnink et al. 2021, Welkers et al. 2021) or L452M, F486L, and N501T mutations which were observed in the receptor binding motif (RBM) of mink SARS-CoV-2 isolates (Elaswad et al. 2020). Notably, the N501T mutation improved the efficiency of SARS-CoV-2 binding to mink and ferret ACE2 receptors which indicate viral adaptation to the mustelid members. Similarly, infection of felines or canines with SARS-CoV-2 resulted in new mutations to adapt to its new host species (Garry 2021).

Different combinations of the previously listed mutations can occur which result in the presence of the different variants such as (453F), (69-70delHV, 453F), (69-70delHV, 453F, $1147 \mathrm{~L})$, and $(69-70 \mathrm{delHV}, 453 \mathrm{~F}, 692 \mathrm{~V}, 1229 \mathrm{I})$ isolates (Lassaunière et al. 2020).

However, the transmissibility potential of mink-related SARS-CoV-2 mutations remained as the original isolates. Even humans infected with cluster 5 did not show additional clinical signs. The prevalence of detection of mink related isolates in the population potentially dropped following culling of farmed minks (ECDC 2020).

Among the reported SARS-CoV-2 mutations are the D614G isolates characterized by the presence of a point mutation in the viral $\mathrm{S}$ protein which led to the substitution of an aspartic acid-to-glycine at amino acid position 614. Mutated isolates were not reported in original Wuhan isolates as they were first identified in late January 2020, and began emerging in March (Zhang et al. 2020b, Daniloski et al. 2021). At that time (March 2020), analysis of SARS-CoV-2 genomes revealed the emergence of four new genetic clusters characterized by being super-spreaders (SSs) (Yang et al. 2020a). The mutated isolates significantly shorter infection doubling time from more than 6 days in original Wuhan isolates to 3 days (Jackson et al. 2021).

This mutation provided a clear phenotypic advantage as it enabled better binding to human ACE2 receptors. The better binding affinity is not only reflected on the speed of spread (up to 8-fold more effective spread than wild-type S-Virus) but also enhanced the infectivity of the virus (3-fold higher viral load in the patients). Therefore, they could rapidly surpass other isolates in prevalence so that most of the circulating strains at present and supplanted S(D614) globally as the predominant form of the virus (Jackson et al. 2021).

The enhancement of the viral binding and ability to enter the cells through the substitution of aspartic acidto-glycine amino acid is not fully understood. However, several hypotheses were suggested such as this substitution: (1) improves the cleavage efficiency of spike protein, (2) reform the shape of the $\mathrm{S}$ protein to favour better RBD-ACE2 interaction, (3) increase the density of the $\mathrm{S}$ proteins on the outer surface of the virus, (4) increases the stability of spike trimers, or possibly (5) the mutated viruses are more resistant to be neutralized by the antibodies (Jackson et al. 2021). 


\section{Documented cases of direct zoonotic and reverse zoonotic COVID-19}

The zoonotic and reverse zoonotic SARS-CoV-2 transmission was reported between human and (1) domestic cats (man to cat) (Hosie et al. 2021) and cat to man (Zhang et al. 2020d, Patterson et al. 2020); (2) man to mink (Oreshkova et al. 2020, Oude Munnink et al. 2020) and mink to man (Oude Munnink et al. 2020); man to ferrets, mice, hamsters, and captive gorillas (Hedman et al. 2021). To the present time, the dogs, lions, and tigers are considered to be dead-end of the infection where man to dog (Sit et al. 2020, Patterson et al. 2020), lion (McAloose et al. 2020), and tiger (McAloose et al. 2020) transmission could be reported but not the reverse one (Figure 2).

\section{One Health approach to control the disease}

SARS-CoV-2 is a serious problem for the international community at present. The virus can invade various body systems and lead to organ dysfunction (El-Sayed et al. 2021a, ElSayed et al. 2021b). The wide host range of SARS-CoV-2 and its geographical distributions raised the alarms of a panzootic accompanying the actual pandemic situation (Enserink 2020, Manes et al. 2020, WHO report 2020, James Gorman 2020). For the pandemic control, several COVID-19 vaccines are now commercially available to prevent further spread of the disease among humans (CDC 2019, Creech et al. 2021) (Table 5). However, despite the present restricted biosecurity measures and early warning surveillance, immunization of human population alone is not enough as the virus started to endemize in all susceptible species to prevent viral spillover back to humans. It is well confirmed that SARS-CoV-2 can infect several domestic and wild animal species and circulate in wild animals. It cannot be excluded that the virus will continue to mutate. Further evolution towards higher fatality or potential to spread, or the occurrence of new mutations is the ongoing present threat. The change in viral antigenicity may lead to failure of coverage by the already available vaccines, increase risk of re-infection, and failure of therapeutic benefits by the administration of monoclonal antibodies or convalescent patients' plasma, which would have catastrophic effects on global public health and economy. Therefore, it is important to apply a robust (One Health approach/Human-Animal-ecosystem) concept to combat the ongoing pandemic and future similar emerging zoonotic disease events (Sharun et al. 2021, Hobbs and Reid 2020). One of the urgent responses among the required measures is developing vaccines for veterinary uses in parallel to those adopted for human use. Pioneer trials to develop COVID-19 animal vaccines were carried out by Zoetis which developed a SARS-CoV-2 vaccine for domestic and zoo animals. The vaccine was primarily designed for and test in pet animals and could provide high protection and safety levels. Following the emergency culling of millions of farmed minks, the vaccine was shifted and adapted to minks (Zoetis 2021). However, in the San Diego Zoo, where at least three gorillas at the Safari Park were naturally infected with the disease, the remaining great apes were subjected to infection risk. Therefore, other non-human primates, including orangutans $(n=4)$ and bonobos $(n=5)$, were emergency vaccinated with Zoetis experimental vaccine (Petersen 2021, Jennewein 2021).

In conclusion, the clear interaction between humans and animal hosts susceptible to SARS-CoV-2 and their capability
Figure 2 Direct zoonotic and reverse zoonotic COVID-19 between humans and animals

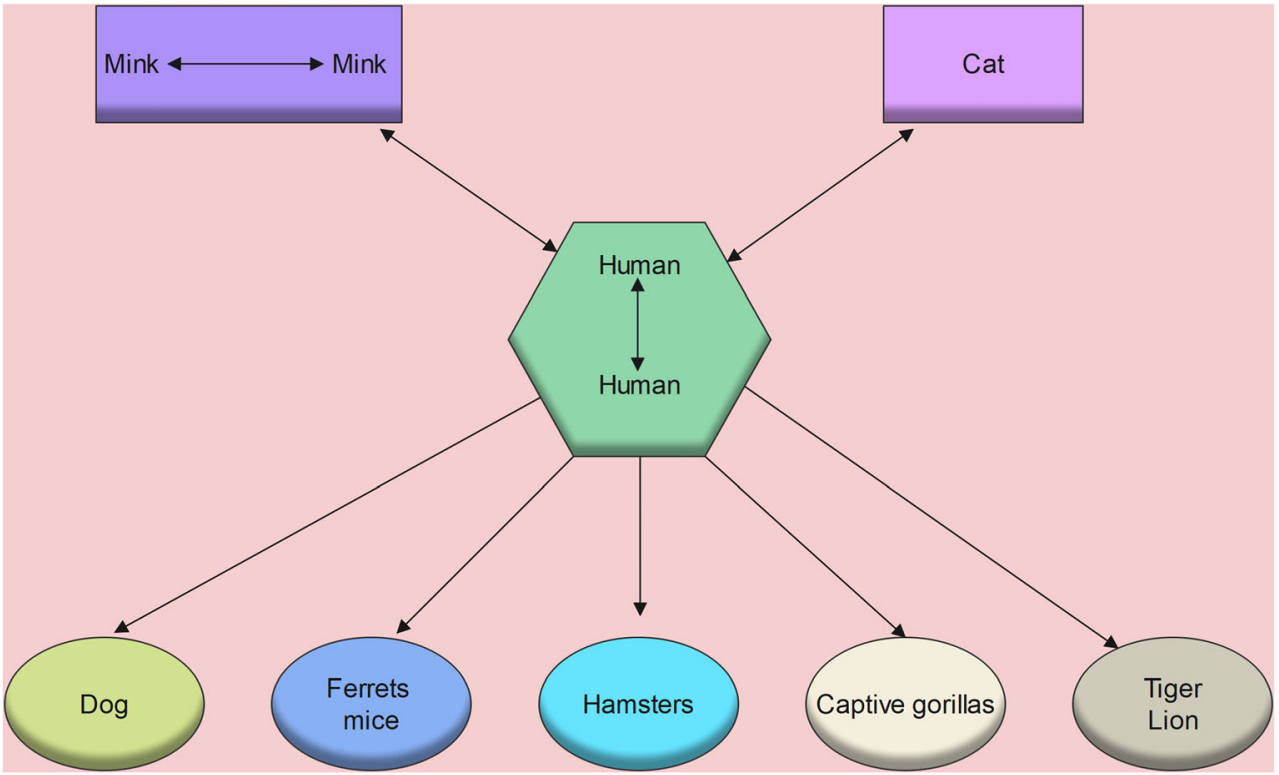


Table 5 The commercially available vaccine for humans and protection against COVID-19. Source: CDC (2019), Creech et al. (2021) in addition to the homepages of the manufacturers

\begin{tabular}{|c|c|c|c|c|c|}
\hline Producer & Types & Efficiency & $\begin{array}{l}\text { Efficiency against } \\
\text { South African isolate }\end{array}$ & Doses & $\begin{array}{l}\text { Storage } \\
\text { conditions }\end{array}$ \\
\hline \multicolumn{6}{|l|}{ Human vaccines } \\
\hline Oxford Astrazeneca & \multirow{3}{*}{$\begin{array}{l}\text { Viral vector vaccine (dsDNA encoding virus } \\
\mathrm{S} \text { protein protected in a virus carrier) }\end{array}$} & $82 \%$ & $10 \%$ & 2 doses (12-week interval) & $2-8{ }^{\circ} \mathrm{C}$ \\
\hline $\mathrm{J} \& \mathrm{~J}$ & & $72 \%$ & $57 \%$ & 1 dose & $2-8^{\circ} \mathrm{C}$ \\
\hline Sputnik V & & $91 \%$ & $?$ & 2 doses (28-day apart) & $2-8^{\circ} \mathrm{C}$ \\
\hline BioNTech/ Pfizer & \multirow{2}{*}{$\begin{array}{l}\text { Encapsulated mRNA vaccine (mRNA encoding } \\
\mathrm{S} \text { protein protected in a lipid nanoparticle) }\end{array}$} & $95 \%$ & $?$ & 2 doses (3-week interval) & $-70^{\circ} \mathrm{C}$ \\
\hline Moderna & & $94.1 \%$ & $?$ & 2 doses (28-day interval) & $-20^{\circ} \mathrm{C}$ \\
\hline Novavax & $\begin{array}{l}\text { Virus-like particle vaccine (coated nanoparticles } \\
\text { with synthetic } S \text { protein and adjuvant) }\end{array}$ & $89 \%$ & $49 \%$ & 2 doses (3 weeks apart) & $2-8^{\circ} \mathrm{C}$ \\
\hline Sinopharm & Inactivated vaccine & $79 \%$ & $?$ & 2 doses ( 3 weeks apart) & $2-8{ }^{\circ} \mathrm{C}$ \\
\hline \multicolumn{6}{|l|}{ Animal vaccine } \\
\hline Zoetis & $\begin{array}{l}\text { Prepared for protection of dogs, cats, and minks } \\
\text { Emergency use for orangutans and bonobos }\end{array}$ & & & & \\
\hline
\end{tabular}

to host new mutations of the virus underlines the importance of developing One Health response strategy for emerging zoonotic disease events and the parallel implementation of disease control strategies in man and animals. The developed vaccines or antiviral preparations used for the control of COVID-19 should be adapted for human and domestic animals susceptible to SARS-CoV-2 to overcome the serious public health threat.

Author contribution $\mathrm{AE}$ and $\mathrm{MK}$ manuscript writing and revision. MMA conducted manuscript moderation and revision. All the authors had contributed, critically reviewed, revised, and approved the final manuscript.

Data availability Not applicable.

\section{Declarations}

Ethical approval Not applicable.

Consent to participate Not applicable

Consent for publication Not applicable.

Competing interests The authors declare no competing interests.

\section{References}

Abdel-Moneim AS, Abdelwhab EM (2020) Evidence for SARS-CoV-2 infection of animal hosts. Pathogens 9(7):529. https://doi.org/10. 3390/pathogens 9070529

APHIS (2020) APHIS. USDA statement on the confirmation of COVID19 in a tiger in New York. Available online: https://www.aphis. usda.gov/aphis/newsroom/news/sa_by_date/sa-2020/NY-zoocovid-19
Azhar EI, Hui DSC, Memish ZA, Drosten C, Zumla A (2019) The Middle East respiratory syndrome (MERS). Infect Dis Clin North Am 33(4):891-905. https://doi.org/10.1016/j.idc.2019.08.001

Bao L, Deng W, Huang B, Gao H, Liu J, Ren L, Wei Q, Yu P, Xu Y, Qi F, Qu Y, Li F, Lv Q, Wang W, Xue J, Gong S, Liu M, Wang G, Wang $S$ et al (2020) The pathogenicity of SARS-CoV-2 in hACE2 transgenic mice. Nature 583(7818):830-833. https://doi.org/10. $1038 / \mathrm{s} 41586-020-2312-y$

Burki T (2021) Understanding variants of SARS-CoV-2. Lancet 397(10273):462. https://doi.org/10.1016/S0140-6736(21)00298-1

Cahan E (2020) COVID-19 hits U.S. mink farms after ripping through Europe. Science. https://doi.org/10.1126/science.abe3870

CDC (2019) CDC reports at https://www.cdc.gov/coronavirus/2019ncov/vaccines/different-vaccines.html)

CDC (2020a) Confirmation of COVID-19 in two pet cats in New York. Available online: https://www.cdc.gov/media/releases/2020/s0422covid-19-cats-NYC.html

CDC (2020b) COVID-19 and animals. https://files.ssi.dk/Mink-cluster5-short-report_AFO2. Accessed 13 Mar 2021

Chan CM, Lau SKP, Woo PCY, Tse H, Zheng B-J, Chen L, Huang J-D, Yuen K-Y (2008) Identification of major histocompatibility complex class i c molecule as an attachment factor that facilitates coronavirus HKU1 spike-mediated infection. J Virol 83(2):1026-1035. https://doi.org/10.1128/jvi.01387-08

Chan JF-W, Zhang AJ, Yuan S, Poon VK-M, Chan CC-S, Lee AC-Y, Chan W-M, Fan Z, Tsoi H-W, Wen L, Liang R, Cao J, Chen Y, Tang K, Luo C, Cai J-P, Kok K-H, Chu H, Chan K-H, Sridhar S, Chen Z, Chen H, To KK-W, Yuen K-Y (2020) Simulation of the clinical and pathological manifestations of coronavirus disease 2019 (COVID-19) in golden Syrian hamster model: implications for disease pathogenesis and transmissibility. Clin Infect Dis:ciaa325. https://doi.org/10.1093/cid/ciaa325

Chen W, Yan M, Yang L, Ding B, He B, Wang Y, Liu X, Liu C, Zhu H, You B, Huang S, Zhang J, Mu F, Xiang Z, Feng X, Wen J, Fang J, Yu J, Yang H, Wang J (2005) SARS-associated coronavirus transmitted from human to pig. Emerg Infect Dis 11(3):446-448. https:// doi.org/10.3201/eid1103.040824

Collins AR (1994) Human coronavirus OC43 interacts with major histocompatibility complex class i molecules at the cell surface to establish infection. Immunological Investigations 23(4-5):313-321. https://doi.org/10.3109/08820139409066826

Contini C, Caselli E, Martini F, Maritati M, Torreggiani E, Seraceni S, Vesce F, Perri P, Rizzo L, Tognon M (2020) COVID-19 is a 
multifaceted challenging pandemic which needs urgent public health interventions. Microorganisms 8(8). https://doi.org/10.3390/ microorganisms 8081228

Corman VM, Muth D, Niemeyer D, Drosten C (2018) Hosts and sources of endemic human coronaviruses. Adv Virus Res 100:163-188. https://doi.org/10.1016/bs.aivir.2018.01.001

Creech CB, Walker SC, Samuels RJ (2021) SARS-CoV-2 vaccines. JAMA. 325:1318-1320. https://doi.org/10.1001/jama.2021.3199

Damas J, Hughes GM, Keough KC, Painter CA, Persky NS, Corbo M, Hiller M, Koepfli K-P, Pfenning AR, Zhao H, Genereux DP, Swofford R, Pollard KS, Ryder OA, Nweeia MT, Lindblad-Toh K, Teeling EC, Karlsson EK, Lewin HA (2020) Broad host range of SARS-CoV-2 predicted by comparative and structural analysis of ACE2 in vertebrates. Proc Natl Acad Sci U S A 117(36):2231122322. https://doi.org/10.1073/pnas.2010146117

Daniloski Z, Jordan TX, Ilmain JK, Guo X, Bhabha G, tenOever BR, Sanjana NE (2021) The Spike D614G mutation increases SARS$\mathrm{CoV}-2$ infection of multiple human cell types. Elife 10:e65365. https://doi.org/10.7554/eLife.65365

Deng J, Jin Y, Liu Y, Sun J, Hao L, Bai J, Huang T, Lin D, Jin Y, Tian K (2020) Serological survey of SARS-CoV-2 for experimental, domestic, companion and wild animals excludes intermediate hosts of 35 different species of animals. Transbound Emerg Dis 67(4): 1745-1749. https://doi.org/10.1111/tbed.13577

ECDC (2020) Detection of new SARS-CoV-2 variants related to mink 12 November 2020. ECDC: Stockholm; 2020. available at https:// psnews.ro/wp-content/uploads/2020/11/document.pdf

Edwards CE, Yount BL, Graham RL, Leist SR, Hou YJ, Dinnon KH, Sims AC, Swanstrom J, Gully K, Scobey TD, Cooley MR, Currie CG, Randell SH, Baric RS (2020) Swine acute diarrhea syndrome coronavirus replication in primary human cells reveals potential susceptibility to infection. Proc Natl Acad Sci U S A 117(43):2691526925. https://doi.org/10.1073/pnas.2001046117

Elaswad A, Fawzy M, Basiouni S, Shehata AA (2020) Mutational spectra of SARS-CoV-2 isolated from animals. PeerJ 8:e10609-e10609. https://doi.org/10.7717/peerj.10609

El-Sayed A, Abdel-Daim MM, Kamel M (2021a) Causes of respiratory failure in COVID-19 patients. Environ Sci Pollut Res 28:1-6. https://doi.org/10.1007/s11356-021-14200-1

El-Sayed A, Aleya L, Kamel M (2021b) COVID-19: a new emerging respiratory disease from the neurological perspective. Environ Sci Pollut Res 28:1-15. https://doi.org/10.1007/s11356-021-12969-9

El-Sayed A, Kamel M (2021) Coronaviruses in humans and animals: the role of bats in viral evolution. Environ Sci Pollut Res 28:1-12. https://doi.org/10.1007/s11356-021-12553-1

Enserink M (2020) Coronavirus rips through Dutch mink farms, triggering culls

Freuling CM, Breithaupt A, Müller T, Sehl J, Balkema-Buschmann A, Rissmann M, Klein A, Wylezich C, Höper D, Wernike K, Aebischer A, Hoffmann D, Friedrichs V, Dorhoi A, Groschup MH, Beer M, Mettenleiter TC (2020) Susceptibility of raccoon dogs for experimental SARS-CoV-2 infection. Emerg Infect Dis 26(12):2982 2985. https://doi.org/10.3201/eid2612.203733

Frutos R, Devaux CA (2020) Mass culling of minks to protect the COVID-19 vaccines: is it rational? New Microbes New Infect 38: 100816. https://doi.org/10.1016/j.nmni.2020.100816

Frutos R, Serra-Cobo J, Chen T, Devaux CA (2020) COVID-19: time to exonerate the pangolin from the transmission of SARS-CoV-2 to humans. Infect Genet Evol 84:104493. https://doi.org/10.1016/j. meegid.2020.104493

Gagneur A, Sizun J, Vallet S, Legr MC, Picard B, Talbot PJ (2002) Coronavirus-related nosocomial viral respiratory infections in a neonatal and paediatric intensive care unit: a prospective study. J Hosp Infect 51(1):59-64. https://doi.org/10.1053/jhin.2002.1179
Garry RF (2021) Mutations arising in SARS-CoV-2 spike on sustained human-to-human transmission and human-to-animal passage. Image 908(1148):292

Gautam A, Kaphle K, Shrestha B, Phuyal S (2020) Susceptibility to SARS, MERS, and COVID-19 from animal health perspective. Open Vet J 10(2):164-177. https://doi.org/10.4314/ovj.v10i2.6

Hammer AS, Quaade ML, Rasmussen TB, Fonager J, Rasmussen M, Mundbjerg K, Lohse L, Strandbygaard B, Jørgensen CS, AlfaroNúñez A, Rosenstierne MW, Boklund A, Halasa T, Fomsgaard A, Belsham GJ, Bøtner A (2021) SARS-CoV-2 transmission between mink (Neovison vison) and Humans, Denmark. Emerg Infect Dis 27(2):547-551. https://doi.org/10.3201/eid2702.203794

Hedman HD, Krawczyk E, Helmy YA, Zhang L, Varga C (2021) Host diversity and potential transmission pathways of SARS-CoV-2 at the human-animal interface. Pathogens 10(2):180. https://doi.org/ $10.3390 /$ pathogens 10020180

Hobbs EC, Reid TJ (2020) Animals and SARS-CoV-2: species susceptibility and viral transmission in experimental and natural conditions, and the potential implications for community transmission. Transbound Emerg Dis. 68:1850-1867. https://doi.org/10.1111/ tbed.13885

Hofmann H, Pyrc K, van der Hoek L, Geier M, Berkhout B, Pöhlmann S (2005) Human coronavirus NL63 employs the severe acute respiratory syndrome coronavirus receptor for cellular entry. Proc Natl Acad Sci U S A 102(22):7988-7993. https://doi.org/10.1073/pnas. 0409465102

Hosie MJ, Hofmann-Lehmann R, Hartmann K, Egberink H, Truyen U, Addie DD, Belák S, Boucraut-Baralon C, Frymus T, Lloret A, Lutz H, Marsilio F, Pennisi MG, Tasker S, Thiry E, Möstl K (2021) Anthropogenic infection of cats during the 2020 COVID-19 pandemic. Viruses 13(2):185. https://doi.org/10.3390/v13020185

Iacobucci G (2021) Covid-19: New UK variant may be linked to increased death rate, early data indicate. BMJ:n230. https://doi.org/ 10.1136/bmj.n230

Jackson CB, Zhang L, Farzan M, Choe H (2021) Functional importance of the D614G mutation in the SARS-CoV-2 spike protein. Biochem Biophys Res Commun 538:108-115. https://doi.org/10.1016/j.bbrc. 2020.11 .026

James Gorman (2020) NCBI news available at https://bit.ly/38A9LjB

Jennewein C (2021) Orangutans and bonobos at zoo get experimental animal COVID vaccine. Times of San Diego

Ji W, Wang W, Zhao X, Zai J, Li X (2020) Cross-species transmission of the newly identified coronavirus 2019-nCoV. J Med Virol 92(4): 433-440. https://doi.org/10.1002/jmv.25682

Jo WK, Oliveira-Filho EF, Rasche A, Greenwood AD, Osterrieder K, Drexler JF (2020) Potential zoonotic sources of SARS-CoV-2 infections. Transbound Emerg Dis. 68:1824-1834. https://doi.org/10. 1111/tbed.13872

Kim Y-I, Kim S-G, Kim S-M, Kim E-H, Park S-J, Yu K-M, Chang J-H, Kim EJ, Lee S, Casel MAB, Um J, Song M-S, Jeong HW, van Lai D, Kim Y, Chin BS, Park J-S, Chung K-H, Foo S-S et al (2020) Infection and rapid transmission of SARS-CoV-2 in ferrets. Cell Host Microbe 27(5):704-709.e2. https://doi.org/10.1016/j.chom. 2020.03.023

Koopmans M (2021) SARS-CoV-2 and the human-animal interface: outbreaks on mink farms. Lancet Infect Dis 21(1):18-19. https://doi. org/10.1016/S1473-3099(20)30912-9

Kumar O.R., V. Ramkumar, Pruthvishree BS, Pande T, Sinha DK, Singh BR, Dhama K, Malik YS (2020) SARS-CoV-2 (COVID-19): zoonotic origin and susceptibility of domestic and wild animals. Journal of Pure and Applied Microbiology 14(suppl 1):741-747. 10.22207/ jpam.14.spl1.11

Lam TT-Y, Jia N, Zhang Y-W, Shum MH-H, Jiang J-F, Zhu H-C, Tong Y-G, Shi Y-X, Ni X-B, Liao Y-S, Li W-J, Jiang B-G, Wei W, Yuan T-T, Zheng K, Cui X-M, Li J, Pei G-Q, Qiang X et al (2020) Identifying SARS-CoV-2-related coronaviruses in Malayan 
pangolins. Nature 583(7815):282-285. https://doi.org/10.1038/ s41586-020-2169-0

Larsen HD, Fonager J, Lomholt FK, Dalby T, Benedetti G, Kristensen B, Urth TR, Rasmussen M, Lassaunière R, Rasmussen TB, Strandbygaard B, Lohse L, Chaine M, Møller KL, Berthelsen ASN, Nørgaard SK, Sönksen UW, Boklund AE, Hammer AS et al (2021) Preliminary report of an outbreak of SARS-CoV-2 in mink and mink farmers associated with community spread, Denmark, June to November 2020. Euro Surveill 26(5):2100009. https://doi. org/10.2807/1560-7917.ES.2021.26.5.210009

Lassaunière R, Fonager J, Rasmussen M, et al (2020) Working paper on SARS-CoV-2 spike mutations arising in Danish mink, their spread to humans and neutralization data

Lau SKP, Woo PCY, Li KSM, Tsang AKL, Fan RYY, Luk HKH, Cai JP, Chan K-H, Zheng B-J, Wang M, Yuen K-Y (2015) Discovery of a novel coronavirus, China Rattus coronavirus HKU24, from Norway rats supports the murine origin of betacoronavirus 1 and has implications for the ancestor of Betacoronavirus lineage A. J Virol 89(6):3076-3092. https://doi.org/10.1128/JVI.02420-14

Lim YX, Ng YL, Tam JP, Liu DX (2016) Human coronaviruses: a review of virus-host interactions. Diseases 4(3):26. https://doi.org/10.3390/ diseases 4030026

Liu Z, Xiao X, Wei X, Li J, Yang J, Tan H, Zhu J, Zhang Q, Wu J, Liu L (2020) Composition and divergence of coronavirus spike proteins and host ACE2 receptors predict potential intermediate hosts of SARS-CoV-2. J Med Virol 92(6):595-601. https://doi.org/10. 1002/jmv.25726

Lu S, Zhao Y, Yu W, Yang Y, Gao J, Wang J, Kuang D, Yang M, Yang J, Ma C, Xu J, Qian X, Li H, Zhao S, Li J, Wang H, Long H, Zhou J, Luo F, Ding K, Wu D, Zhang Y, Dong Y, Liu Y, Zheng Y, Lin X, Jiao L, Zheng H, Dai Q, Sun Q, Hu Y, Ke C, Liu H, Peng X (2020) Comparison of SARS-CoV-2 infections among 3 species of nonhuman primates. https://doi.org/10.1101/2020.04.08.031807

Luan J, Jin X, Lu Y, Zhang L (2020) SARS-CoV-2 spike protein favors ACE2 from Bovidae and Cricetidae. J Med Virol:10.1002/ jmv.25817https://doi.org/10.1002/jmv.25817

Mallapaty S (2020) Coronavirus can infect cats - dogs, not so much. Nature. https://doi.org/10.1038/d41586-020-00984-8

Manes C, Gollakner R, Capua I (2020) Could Mustelids spur COVID-19 into a panzootic? Veterinaria italiana

McAloose D, Laverack M, Wang L, Killian ML, Caserta LC, Yuan F, Mitchell PK, Queen K, Mauldin MR, Cronk BD, Bartlett SL, Sykes JM, Zec S, Stokol T, Ingerman K, Delaney MA, Fredrickson R, Ivančić M, Jenkins-Moore M, Mozingo K, Franzen K, Bergeson NH, Goodman L, Wang H, Fang Y, Olmstead C, McCann C, Thomas P, Goodrich E, Elvinger F, Smith DC, Tong S, Slavinski S, Calle PP, Terio K, Torchetti MK, Diel DG (2020) From people to Panthera: natural SARS-CoV-2 infection in tigers and lions at the Bronx Zoo. https://doi.org/10.1101/2020.07.22.213959

Muik A, Wallisch A-K, Sänger B, Swanson KA, Mühl J, Chen W, Cai H, Maurus D, Sarkar R, Türeci Ö, Dormitzer PR, Şahin U (2021) Neutralization of SARS-CoV-2 lineage B.1.1.7 pseudovirus by BNT162b2 vaccine-elicited human sera. Science 371(6534): 1152-1153. https://doi.org/10.1126/science.abg6105

Munster VJ, Feldmann F, Williamson BN, van Doremalen N, PérezPérez L, Schulz J, Meade-White K, Okumura A, Callison J, Brumbaugh B, Avanzato VA, Rosenke R, Hanley PW, Saturday G, Scott D, Fischer ER, de Wit E (2020) Respiratory disease and virus shedding in rhesus macaques inoculated with SARS-CoV-2. bioRxiv:2020.03.21.001628. 10.1101/2020.03.21.001628

OIE (2020a) A case of a Belgian cat positive for Covid-19. Available online: https://www.oie.int/fileadmin/Home/eng/Our_scientific expertise/docs/pdf/COV-19/Belgium 28.03.20.pdf

OIE (2020b) COVID-19 (SARS-COV-2), available under https://www. oie.int/wahis 2/public/wahid.php/Reviewreport/Review?reportid= 34054
OIE (2020c) COVID-19 (SARS-COV-2), Hong Kong (SAR - PRC) 2020. Available online: https://www.oie.int/wahis_2/public/wahid. php/Reviewreport/Review? pa ge_refer $=$ MapFullEventReport\&reportid=33546. Accessed on 22 June 2020

OIE (2021) Events in animals: OIE - World Organisation for Animal Health. https://www.oie.int/en/scientific-expertise/specificinformation-and-recommendations/questions-and-answers-on2019novel-coronavirus/events-in-animals. Accessed 13 Mar 2021. $113 Z$

Oreshkova N, Molenaar RJ, Vreman S, Harders F, Oude Munnink BB, der Honing H-v, Renate W, Gerhards N, Tolsma P, Bouwstra R, Sikkema RS, Tacken MG, de Rooij MM, Weesendorp E, Engelsma MY, Bruschke CJ, Am Smit L, Koopmans M, van der Poel WH, Stegeman A (2020) SARS-CoV-2 infection in farmed minks, the Netherlands, April and May 2020. Euro Surveill 25(23):2001005. https://doi.org/10.2807/1560-7917.ES.2020.25.23.2001005

Oude Munnink BB, Sikkema RS, Nieuwenhuijse DF, Molenaar RJ, Munger E, Molenkamp R, van der Spek A, Tolsma P, Rietveld A, Brouwer M, Bouwmeester-Vincken N, Harders F, der Honing RH, Wegdam-Blans MC, Bouwstra RJ, GeurtsvanKessel C, van der Eijk, Annemiek A., Velkers FC, Smit LA, Stegeman A, van der Poel, Wim H.M., Koopmans MP (2020) Jumping back and forth: anthropozoonotic and zoonotic transmission of SARS-CoV-2 on mink farms. https://doi.org/10.1101/2020.09.01.277152

Oude Munnink BB, Sikkema RS, Nieuwenhuijse DF, Molenaar RJ, Munger E, Molenkamp R, van der Spek A, Tolsma P, Rietveld A, Brouwer M, Bouwmeester-Vincken N, Harders F, Hakze-van der Honing R, Wegdam-Blans MCA, Bouwstra RJ, GeurtsvanKessel C, van der Eijk AA, Velkers FC, Smit LAM et al (2021) Transmission of SARS-CoV-2 on mink farms between humans and mink and back to humans. Science 371(6525):172-177. https://doi.org/10. 1126/science.abe5901

Patterson EI, Elia G, Grassi A, Giordano A, Desario C, Medardo M, Smith SL, Anderson ER, Prince T, Patterson GT, Lorusso E, Lucente MS, Lanave G, Lauzi S, Bonfanti U, Stranieri A, Martella V, Solari Basano F, Barrs VR et al (2020) Evidence of exposure to SARS-CoV-2 in cats and dogs from households in Italy. Nat Commun 11(1):6231. https://doi.org/10.1038/s41467-020-20097-0

Petersen J (2021) In what's believed to be a first among great apes, several gorillas at San Diego Zoo in the US have been infected with COVID-19. | World News Australia. https://search.informit.org/ doi/10.3316/TVNEWS.TSM202101120060. Accessed 13 Mar $2021.452 Z$

Praharaj MR, Garg P, Khan RIN, Sharma S, Panigrahi M, Mishra BP, Mishra B, Gandham RK, Singh RK, Majumdar S (2020) Prediction analysis of SARS-COV-2 entry in Livestock and Wild animals. bioRxiv

Rafael Bayarri-Olmos, Anne Rosbjerg, Laust Bruun Johnsen, Charlotte Helgstrand, Theresa Bak-Thomsen, Peter Garred, Mikkel-Ole Skjoedt (2021) The SARS-CoV-2 Y453F mink variant displays a striking increase in ACE-2 affinity but does not challenge antibody neutralization. bioRxiv:2021.01.29.428834.10.1101/ 2021.01.29.428834

Ruiz-Arrondo I, Portillo A, Palomar AM, Santibanez S, Santibanez P, Cervera C, Oteo JA (2020) Detection of SARS-CoV-2 in pets living with COVID-19 owners diagnosed during the COVID-19 lockdown in Spain: a case of an asymptomatic cat with SARS-CoV-2 in Europe. https://doi.org/10.1101/2020.05.14.20101444

Salajegheh Tazerji S, Magalhães Duarte P, Rahimi P, Shahabinejad F, Dhakal S, Singh Malik Y, Shehata AA, Lama J, Klein J, Safdar M, Rahman MT, Filipiak KJ, Rodríguez-Morales AJ, Sobur MA, Kabir F, Vazir B, Mboera L, Caporale M, Islam MS et al (2020) Transmission of severe acute respiratory syndrome coronavirus 2 (SARS-CoV-2) to animals: an updated review. J Transl Med 18(1):358. https://doi.org/10.1186/s12967-020-02534-2 
Santini JM, Edwards SJL (2020) Host range of SARS-CoV-2 and implications for public health. Lancet Microbe 1(4):e141-e142. https:// doi.org/10.1016/S2666-5247(20)30069-0

Schlottau K, Rissmann M, Graaf A, Schön J, Sehl J, Wylezich C, Höper D, Mettenleiter TC, Balkema-Buschmann A, Harder T, Grund C, Hoffmann D, Breithaupt A, Beer M (2020) SARS-CoV-2 in fruit bats, ferrets, pigs, and chickens: an experimental transmission study. Lancet Microbe 1(5):e218-e225. https://doi.org/10.1016/S26665247(20)30089-6

Sharun K, Tiwari R, Natesan S, Dhama K (2021) SARS-CoV-2 infection in farmed minks, associated zoonotic concerns, and importance of the One Health approach during the ongoing COVID-19 pandemic. Vet Q 41(1):50-60. https://doi.org/10.1080/01652176.2020. 1867776

Shi J, Wen Z, Zhong G, Yang H, Wang C, Huang B, Liu R, He X, Shuai L, Sun Z, Zhao Y, Liu P, Liang L, Cui P, Wang J, Zhang X, Guan Y, Tan W, Wu G et al (2020) Susceptibility of ferrets, cats, dogs, and other domesticated animals to SARS-coronavirus 2. Science 368(6494):1016-1020. https://doi.org/10.1126/science.abb7015

Shriner SA, Ellis JW, Root JJ, Roug A, Stopak SR, Wiscomb GW, Zierenberg JR, Ip HS, Torchetti MK, DeLiberto TJ (2021) SARSCoV-2 exposure in escaped mink, Utah, USA. Emerg Infect Dis 27(3):988-990. https://doi.org/10.3201/eid2703.204444

Sia SF, Yan L-M, Chin AWH, Fung K, Choy K-T, Wong AYL, Kaewpreedee P, Perera RAPM, Poon LLM, Nicholls JM, Peiris M, Yen H-L (2020) Pathogenesis and transmission of SARS-CoV2 in golden hamsters. Nature 583(7818):834-838. https://doi.org/ 10.1038/s41586-020-2342-5

Singla R, Mishra A, Joshi R, Jha S, Sharma AR, Upadhyay S, Sarma P, Prakash A, Medhi B (2020) Human animal interface of SARS-CoV2 (COVID-19) transmission: a critical appraisal of scientific evidence. Vet Res Commun 44(3-4):119-130. https://doi.org/10. 1007/s11259-020-09781-0

Sit THC, Brackman CJ, Ip SM, Tam KWS, Law PYT, To EMW, Yu VYT, Sims LD, Tsang DNC, Chu DKW (2020) Infection of dogs with SARS-CoV-2. Nature:1-6

Starr TN, Greaney AJ, Addetia A, Hannon WW, Choudhary MC, Dingens AS, Li JZ, Bloom JD (2021) Prospective mapping of viral mutations that escape antibodies used to treat COVID-19. Science 371(6531):850-854. https://doi.org/10.1126/science.abf9302

Stout AE, Guo Q, Millet JK, de Matos R, Whittaker GR (2021) Coronaviruses associated with the superfamily Musteloidea. mBio 12(1):e02873-20. 10.1128/mBio.02873-20

Suarez DL, Pantin-Jackwood MJ, Swayne DE, Lee SA, DeBlois SM, Spackman E (2020) Lack of susceptibility of poultry to SARSCoV-2 and MERS-CoV. https://doi.org/10.1101/2020.06.16. 154658

Supasa P, Zhou D, Dejnirattisai W, Liu C, Mentzer AJ, Ginn HM, Zhao Y, Duyvesteyn HM, Nutalai R, Tuekprakhon A, Wang B, Paesen GC, Slon-Campos J, López-Camacho C, Hallis B, Coombes N, Bewley K, Charlton S, Walter TS, Barnes E, Dunachie SJ, Skelly D, Lumley SF, Baker N, Shaik I, Humphries H, Godwin K, Gent N, Sienkiewicz A, Dold C, Levin R, Dong T, Pollard AJ, Knight JC, Klenerman P, Crook D, Lambe T, Clutterbuck E, Bibi S, Flaxman A, Bittaye M, Belij-Rammerstorfer S, Gilbert S, Hall DR, Williams MA, Paterson NG, James W, Carroll MW, Fry EE, Mongkolsapaya J, Ren J, Stuart DI, Screaton GR (2021) Reduced neutralization of SARS-CoV-2 B.1.1.7 variant by convalescent and vaccine sera. Cell. https://doi.org/10.1016/j.cell.2021.02.033

Swelum AA, Shafi ME, Albaqami NM, El-Saadony MT, Elsify A, Abdo M, Taha AE, Abdel-Moneim A-ME, Al-Gabri NA, Almaiman AA, Saleh Al-Wajeeh A, Tufarelli V, Staffa VN, Abd El-Hack ME (2020) COVID-19 in human, animal, and environment: a review. Front Vet Sci 7:578. https://doi.org/10.3389/fvets.2020.00578

Tang X, Wu C, Li X, Song Y, Yao X, Wu X, Duan Y, Zhang H, Wang Y, Qian Z, Cui J, Lu J (2020) On the origin and continuing evolution of
SARS-CoV-2. National Science Review 7(6):1012-1023. https:// doi.org/10.1093/nsr/nwaa036

USDA (2020) Confirmed cases of SARS-CoV-2 in animals in the United States. Available at https://www.aphis.usda.gov/aphis/ourfocus/ animalhealth/sa one health/sars-cov-2-animals-us

Vergara-Alert J, van den Brand JMA, Widagdo W, Muñoz M, Raj S, Schipper D, Solanes D, Cordón I, Bensaid A, Haagmans BL, Segalés J (2017) Livestock susceptibility to infection with Middle East respiratory syndrome coronavirus. Emerg Infect Dis 23(2): 232-240. https://doi.org/10.3201/eid2302.161239

Wang M, Jing HQ, Xu HF, Jiang XG, Kan B, Liu QY, Wan KL, Cui BY, Zheng H, Cui ZG (2005) Surveillance on severe acute respiratory syndrome associated coronavirus in animals at a live animal market of Guangzhou in 2004. Zhonghua liu xing bing xue za zhi= Zhonghua liuxingbingxue zazhi 26(2):84-87

Welkers MRA, Han AX, Reusken, Chantal B E M, Eggink D (2021) Possible host-adaptation of SARS-CoV-2 due to improved ACE2 receptor binding in mink. Virus Evol 7(1). https://doi.org/10.1093/ ve/veaa094

WHO report (2020) SARS-CoV-2 mink-associated variant strain Denmark available at: https://bit.ly/3kd5lB4

de Wit E, Rasmussen AL, Falzarano D, Bushmaker T, Feldmann F, Brining DL, Fischer ER, Martellaro C, Okumura A, Chang J, Scott D, Benecke AG, Katze MG, Feldmann H, Munster VJ (2013) Middle East respiratory syndrome coronavirus (MERS$\mathrm{CoV}$ ) causes transient lower respiratory tract infection in rhesus macaques. Proc Natl Acad Sci U S A 110(41):16598-16603. https://doi.org/10.1073/pnas.1310744110

Wong MC, Javornik Cregeen SJ, Ajami NJ, Petrosino JF (2020) Evidence of recombination in coronaviruses implicating pangolin origins of nCoV-2019. bioRxiv:2020.02.07.939207. https://doi. org/10.1101/2020.02.07.939207

Wu D, Tu C, Xin C, Xuan H, Meng Q, Liu Y, Yu Y, Guan Y, Jiang Y, Yin X, Crameri G, Wang M, Li C, Liu S, Liao M, Feng L, Xiang H, Sun J, Chen J et al (2005) Civets are equally susceptible to experimental infection by two different severe acute respiratory syndrome coronavirus isolates. J Virol 79(4):2620-2625. https://doi.org/10. 1128/JVI.79.4.2620-2625.2005

Wu L, Chen Q, Liu K, Wang J, Han P, Zhang Y, Hu Y, Meng Y, Pan X, Qiao C, Tian S, Du P, Song H, Shi W, Qi J, Wang H-W, Yan J, Gao GF, Wang Q (2020) Broad host range of SARS-CoV-2 and the molecular basis for SARS-CoV-2 binding to cat ACE2. Cell Discov 6:68. https://doi.org/10.1038/s41421-020-00210-9

Yang X, Dong N, Chan EW-C, Chen S (2020a) Genetic cluster analysis of SARS-CoV-2 and the identification of those responsible for the major outbreaks in various countries. Emerg Microbes Infect 9(1): 1287-1299. https://doi.org/10.1080/22221751.2020.1773745

Yang Y-L, Yu J-Q, Huang Y-W (2020b) Swine enteric alphacoronavirus (swine acute diarrhea syndrome coronavirus): an update three years after its discovery. Virus Res 285:198024. https://doi.org/10.1016/j. virusres.2020.198024

Zhang C, Zheng W, Huang X, Bell EW, Zhou X, Zhang Y (2020a) Protein structure and sequence reanalysis of $2019-\mathrm{nCoV}$ genome refutes snakes as its intermediate host and the unique similarity between its spike protein insertions and HIV-1. J Proteome Res 19(4):1351-1360. https://doi.org/10.1021/acs.jproteome.0c00129

Zhang L, Jackson CB, Mou H, Ojha A, Rangarajan ES, Izard T, Farzan M, Choe H (2020b) The D614G mutation in the SARS-CoV-2 spike protein reduces $\mathrm{S} 1$ shedding and increases infectivity. bioRxiv: 2020.06.12.148726. https://doi.org/10.1101/2020.06.12.148726

Zhang N, Xu Q, Zhang R, Zhao J (2020c) A comment on "Serological survey of SARS-CoV-2 for experimental, domestic, companion and wild animals excludes intermediate hosts of 35 different species of animals".

Zhang Q, Zhang H, Gao J, Huang K, Yang Y, Hui X, He X, Li C, Gong W, Zhang Y, Zhao Y, Peng C, Gao X, Chen H, Zou Z, Shi Z-L, Jin 
M (2020d) A serological survey of SARS-CoV-2 in cat in Wuhan. Emerg Microbes Infect 9(1):2013-2019. https://doi.org/10.1080/ 22221751.2020 .1817796

Zhang T, Wu Q, Zhang Z (2020e) Probable pangolin origin of SARSCoV-2 associated with the COVID-19 outbreak. Curr Biol 30(7): 1346-1351.e2. https://doi.org/10.1016/j.cub.2020.03.022

Zhao Y, Wang J, Kuang D, Xu J, Yang M, Ma C, Zhao S, Li J, Long H, Ding K (2020) Susceptibility of tree shrew to SARS-CoV-2 infection. bioRxiv

Zhu N, Zhang D, Wang W, Li X, Yang B, Song J, Zhao X, Huang B, Shi W, Lu R, Niu P, Zhan F, Ma X, Wang D, Xu W, Wu G, Gao GF, Tan W, China Novel Coronavirus Investigating and Research Team
(2020) A novel coronavirus from patients with pneumonia in China, 2019. N Engl J Med 382(8):727-733. https://doi.org/10.1056/ NEJMoa2001017

Zoetis (2021) COVID-19 animal vaccines | Zoetis. https://www.zoetis. $\mathrm{com} /$ news-and-media/feature-stories/posts/zoetis-emerginginfectious-disease-capabilities-support-covid-19-solutions-forgreat-apes-and-minks.aspx. Accessed 13 Mar 2021.

Publisher's note Springer Nature remains neutral with regard to jurisdictional claims in published maps and institutional affiliations. 